\title{
Probiotics as alternative control measures in shrimp aquaculture: A review
}

\author{
Mamdoh T. Jamal, Idres A. Abdulrahman, Mamdouh Al Harbi, Sambhu Chithambaran* \\ Department of Marine Biology, Faculty of Marine Sciences, King Abdulaziz University, P.O Box 80207, Jeddah, Kingdom of Saudi Arabia
}

\begin{tabular}{|c|c|}
\hline ARTICLE INFO & ABSTRACT \\
\hline $\begin{array}{l}\text { Article history: } \\
\text { Received on: September 27, } 2018 \\
\text { Accepted on: October 29, } 2018 \\
\text { Available online: April 05, } 2019\end{array}$ & \multirow{2}{*}{$\begin{array}{l}\text { Shrimp aquaculture industry is facing diseases problems, viral and bacterial pathogens that take advantage of the } \\
\text { weak immunity of shrimp and an altered gut microbial community. Furthermore, probiotic practices in aquaculture } \\
\text { started to be of importance for increased disease resistant, aquatic organisms growth, and feed efficiency. Later they } \\
\text { are used to improve the water quality of bacterial infections. Today, there is an evidence that probiotics can improve } \\
\text { the digestibility of nutrients, increase tolerance to stress, and encourage reproduction. They are substances containing } \\
\text { live microorganisms secreted by microorganisms that stimulate the growth of other organisms. At presently, many } \\
\text { commercial probiotic products made by bacterial species such as Lactobacillus sp., Bacillus sp., Carnobacterium sp., } \\
\text { Enterococcus sp., and also from yeast, i.e., Saccharomyces cerevisiae are available. This review article gives a brief } \\
\text { explanation on probiotics, their types, origin, mode of action, types of diseases they can control, ability to improve } \\
\text { nutrients digestion, increase stress tolerance, and increase of reproduction. }\end{array}$} \\
\hline $\begin{array}{l}\text { Key words: } \\
\text { Disease control, } \\
\text { Immunomodulation, } \\
\text { Probiotics, } \\
\text { Shrimp culture }\end{array}$ & \\
\hline
\end{tabular}

\section{INTRODUCTION}

Aquaculture is the culture of organisms in controlled aquatic environments [1]. Fish aquaculture has remain an important financial source and has boost the economy of many developing countries and served as an important source of food, nutrition, income, and livelihoods for many people around the globe [1]. Due to rapid growth and advancement in aquaculture, the report by indicates that aquaculture is responsible for the provision of about $50 \%$ of all fish consumed by humans and the world per capita fish supply has reached a new record high of $20 \mathrm{~kg}$ in 2014 [1]. This is a clear demonstration of the contribution of marine environment and inland waters to food security as the world population is expected to rise to over 9 billion people in 2050 .

Marine shrimp aquaculture has been the mainstay of aquaculture industries due to shrimp's richness in protein supply [1]. Shrimp aquaculture is a common practice in developing nations in Asia, Latin America and throughout the tropical world supporting nonurban communities with means of survival, and consequently reduced poverty [1]. It contributes to over $50 \%$ of global shrimp production as cached shrimp cannot serve the export demand for shrimp worldwide and is regarded as the most valued aquaculture business.

*Corresponding Author:

Sambhu Chithambaran,

Department of Marine Biology, Faculty of Marine Sciences,

King Abdulaziz University, P.O Box 80207, Jeddah, Kingdom of Saudi Arabia. Tel.: +966552790434,

Email: sambhu@kau.edu.sa
Black tiger shrimp (Penaeus monodon) is the most widely cultured species in many countries, but due to the emergence of viral pathogens, many farmers have switched to the imported Pacific whiteleg shrimp, Litopenaeus vannamei which has been genetically selected and has since 2003 become a domesticated stock [2,3]. Most developing countries have embraced shrimp farming and are serving as a major export commodity (in international trade) to the developing world. The industry is rapidly growing with 7 million metric tons annual production, generating billions of dollars every year in trade (currently worth around US\$10 billion or $16 \%$ of all fishery exports), employs millions of people globally and set for a period of strongly growing demand [4]. Considerable achievements have been made in the aquaculture sector to improve production; and disease resistance; however, information on the use of probiotics as control measures for the disease are scanty. Therefore, this review is an effort taken to understand the role of probiotics as an alternate source for disease control in shrimp aquaculture.

\subsection{Shrimp Aquaculture Diseases}

Despite the accelerated development in global aquaculture of shrimp, the farming industry in the past decades, faced different pathogenic diseases, which reported to cause substantial economic losses [5]. The emergence of this major challenge of shrimp diseases has threatened the success and prospect recorded in the business of shrimp farming [2,4]. This has dwarfed the aquaculture of shrimp and relegated it to the second position in terms of value added product after being the most traded product for decades [5]. Outbreak of diseases has led to a significant reduction in shrimp production and had taken many farmers out of business by converting shrimp ponds to catfish ponds, especially in India [6]. The infections devastated the economic

(C) 2019 Jamal, et al. This is an open access article distributed under the terms of the Creative Commons Attribution License -NonCommercial-ShareAlike

Unported License (http://creativecommons.org/licenses/by-nc-sa/3.0/). 
and societal benefits of shrimp farming with an estimated total loss exceeding $40 \%$ of the global production capacity [7].

Infectious diseases in shrimp are caused by viral, bacterial, and eukaryote pathogens as well as some abiotic factors. Infectious diseases have become a stumbling block for expansion of shrimp aquaculture due to losses recorded [8]. Most of these losses have been attributed to viruses, which account for $60 \%$, an estimated $20 \%$ has been attributed to bacteria while eukaryotes such as fungi and parasites' losses are comparably low [3]. Shrimp diseases caused by opportunistic bacteria such as Vibrio sp. and viruses are the major problems that can lead to huge losses in farmed shrimp industry [2].

Shrimp viral diseases that account for almost $60 \%$ of all shrimp losses in shrimp aquaculture are caused mainly by some viruses, namely infectious hypodermal and hematopoietic necrosis virus, Taura syndrome virus, white spot syndrome virus (WSSV), yellow head virus (YHV), and infectious myonecrosis virus [5]. WSSV and YHV are the most lethal and affect both the wild (P. monodon) and the domesticated (P. vannamei) species [3]. Others are exclusively diseases of $P$. monodon which occurs when captured ones are used for larvae production such as monodon slow growth syndrome, hepatopancreatic parvovirus, and monodon baculovirus [3]. Most viral diseases proliferate and make substantive impact when wild-caught broodstock are used in hatchery production to supply millions of larvae to stock the ponds and importation of live shrimp for aquaculture [6]. Although to date, there have been no effective drugs for the control and treatment for viral infections, the farming industry can be transformed in a safe manner through adequate preventive measures such as rigorous sanitary practices, introduction of tolerant stocks, adoption of new technologies, implementation of good biosecurity practices, and rapid diagnosis of domesticated stocks $[1,5]$. Biosecurity measures will ensure the exclusion of specific pathogens from cultured aquatic stocks in broodstock facilities, hatcheries, and farms, and secured environment [9]. This can be promising in global shrimp farming in reducing the impact of losses in shrimp production due to viral diseases. The market has since opened a new chapter of rapid growth due to its recovery from major viral pandemics [1].

Unlike viruses, bacterial diseases of shrimp are mostly caused by various species of Vibrio [10]. In most diseased shrimp studies, Vibrio species are the frequent bacterial flora that causes vibriosis [2]. The pathogens have led to the collapse of many farms due to its severe effect on hatcheries and high rate of morbidity and mortality. In the world of shrimp aquaculture, vibriosis has been a major problem and capable of crippling shrimp culture ponds with consequent huge economic losses $[11,12]$. The strength of infection depends on the organisms and strain of Vibrio involved the stage of development and age of shrimp, and the ambient environmental conditions [13]. The disease manifests when shrimps are weakened or when pond conditions favor the survival, growth, and spread of bacterial pathogens [12]. These conditions include water availability, large number of shrimps in hatchery, regular use of feed that is rich in protein and when environmental conditions are favorable. The several diseases caused by Vibrio species include loose shell syndrome (LSS), white gut disease (WGD), tail necrosis, shell disease and red disease of which LSS, WGD, and red disease caused mass mortalities in shrimp culture ponds [13].

\subsection{Control of Shrimp Disease}

The special concern today is focused on how to effectively control and prevent outbreak of diseases in shrimps. In practice, control of shrimp bacterial infections has relied solely on the use of antibiotics and antimicrobial disinfectants or chemical additives [6]. Moriarty reported that many farmers apply antibiotics in large quantity as a preventive measure even when infections are not apparent [2]. This has consequently resulted in an increase in the multiple antibiotic resistance strains of virulent pathogenic vibriosis through mutations which has been linked to the ability of marine vibriosis to use plasmids to transfer antibiotic resistance genes between the large bacterial pond population density [14]. The marine pathogen Vibrio parahaemolyticus becomes severe using a plasmid that expresses a deadly toxin [2]. Biofilm formation allows Vibrio species to thrive on surfaces even in the presence of antibiotics which also pose a challenge in the management of shrimp diseases by protecting the bacteria against antibiotics [6]. The use of chemical agents has also been challenged due to the resultant adverse environmental effects [15]. It can accumulate in the shrimp making it unattractive for export.

To effectively manage shrimp diseases, alternative control and management measures are required [10]. This has necessitated the intense search for an environmentally friendly alternative treatment control of shrimp diseases in aquaculture that will be used to overcome the threat of antimicrobial resistance and ensure sustainable, safe and healthy food production for the growing world population. One of the effective alternatives is the use of antibacterial probiotics as an environmentally friendly approach. This approach is capable of disease control in aquaculture, especially against bacterial diseases; however, its use against viruses is still a subject of research. It is newer and safer to use with its capability to improve the animal's nonspecific immune system.

\subsection{Definition, Source, and Potential Needs}

Probiotic was best defined by Fuller as "a live microbial feed supplement which beneficially affects the host animal by improving its intestinal microbial balance" [16]. The probiotics also called beneficial bacteria are capable of improving the host's health status when consumed [17]. They cause inhibition of the pathogens growth in the host, improve the host's innate immunity and hence regarded as a replacement for antibiotic treatments. Probiotics can be commercialized; administered orally and obtained from the animal's host. It can be a single or culture of mixed nonpathogenic bacteria. Its work is based on the introduction into the culture system of harmless and beneficial bacteria that will have a competitive advantage over potential pathogens and also to colonize the ecological niche [17]. The probiotics can overcome the effect of pathogens and increase the survival of the host [10].

Verschuere et al. proposed a broader definition of probiotics in aquaculture "as a live microbial audit which has a beneficial effect on the host by modifying the host-associated, ambient microbial community through improvement of its feed or enhancing its nutritional value and also by enhancing the host response toward disease, or by improving the quality of its ambient environment" [18]. Probiotics improve the health status of the shrimp by resisting colonization of pathogens through competition, releasing metabolites that prevent the growth of pathogens and thus increasing the shrimp resistance to diseases [Table 1 and Figure 1].

Table 1: Application of probiotic for nutrient digestibility

\begin{tabular}{llc} 
Probiotic Identified & Applied to aquatic species & Reference \\
Lactobacillus helveticus & Scophthalmus maximus & {$[19]$} \\
Bacillus NL 110, Vibrio NE 17 & Macrobrachium rosenbergii & {$[20]$} \\
Carnobacterium sp. Hg4-03 & Hepialus gonggaensis larvae & {$[21]$} \\
Lactobacillus acidophilus & Clarias gariepinus & {$[22]$} \\
Shewanella putrefaciens Pdp11 & Solea senegalensis & {$[23]$} \\
\hline
\end{tabular}




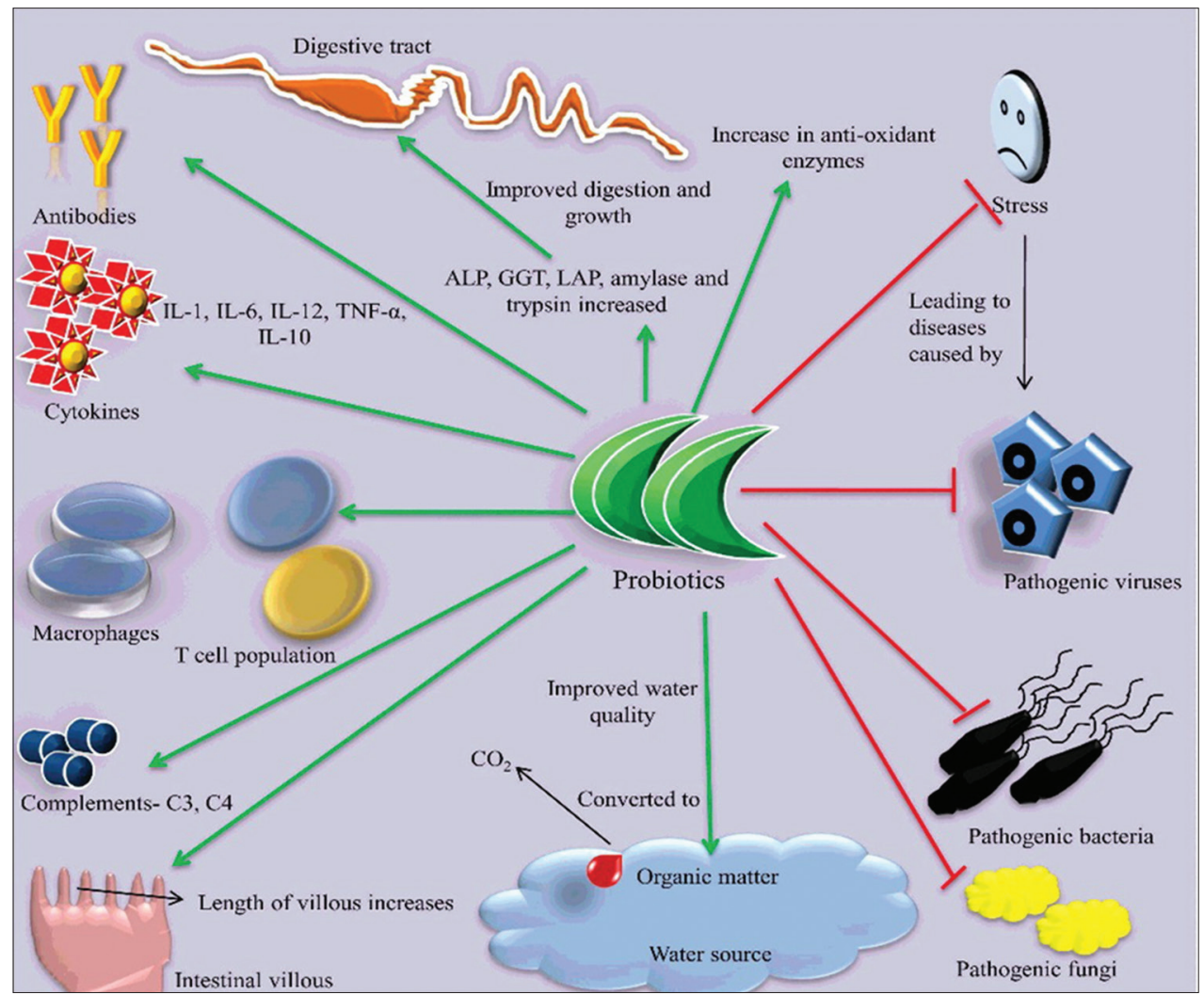

Figure 1: Overall beneficial effects of probiotic in Aquaculture. Green arrow indicates additive effects. Red lines indicate inhibitory effect

The use of probiotics in the control of diseases in aquaculture of shrimp is being accepted with several researchers showing promising result due to demands for the eco-friendly approach in aquaculture, but it still requires many full scale trials [24]. The use of probiotic bacteria has become increasingly popular for improved nutrition, healthy digestion, and disease prevention. It has been successfully applied in the control of shrimp and other aquatic animal diseases in many developing countries [25]. Probiotics improve the health status of the shrimp by resisting colonization of pathogens through competition, releasing metabolites that prevent the growth of pathogens and thus increasing the shrimp resistance to diseases [10] [Figure 1]. Wang et al. have said this qualified probiotic organism needs to be applied for the safe management of shrimp diseases in aquaculture [26].

\section{ORGANISMS INVOLVED IN AQUATIC PROBIOTICS}

In aquaculture practice, probiotics are used as live food supplement and applied in pure or mixed form to increase water quality and enhance immune responses. Many organisms are tested for use as probiotics in aquaculture, including Gram-negative and Gram-positive bacteria, bacteriophages, yeasts, and unicellular algae [27]. The probiotic strains isolated from both indigenous and exogenous microbiota of aquatic animals [28]. Probiotics could be common obtained from various sources that include the gastrointestinal (GI) tracts of aquatic animals and fish mucus [29,30]. In addition, the sources can also be from aquatic environment water or sediment or also could be isolated from microbial bioflakes [28,31]. Some of the potential probiotics are associated with the host, and they have an edge over others due to their biochemical factors [32]. Isolated bacteria from the intestine of aquatic and terrestrial animals are usually and commonly used as probiotics in aquaculture [33].
Table 2: Probiotic bacteria identified as growth promoters

\begin{tabular}{llc} 
Probiotic identified & Aquatic species & Reference \\
Bacillus sp. S11 & Penaeus monodon & {$[35]$} \\
Bacillus sp. & Catfish & {$[36]$} \\
Carnobacterium divergens & Gadus morhua & {$[37]$} \\
Alteromonas CA2 & Crassostrea gigas & {$[38]$} \\
Lactobacillus helveticus & Scophthalmus Maximus & {$[19]$} \\
Lactobacillus lactis AR21 & Brachionus plicatilis & {$[39]$} \\
Streptococcus thermophilus & Scophthalmus maximus & {$[39]$} \\
Streptomyces & Xiphophorus helleri & {$[40]$} \\
Lactobacillus casei & Poeciliopsis gracilis & {$[41]$} \\
Bacillus NL 110, Vibrio NE 17 & Macrobrachium rosenbergii & {$[20]$} \\
Bacillus coagulans & Cyprinus carpio koi & {$[42]$} \\
\hline
\end{tabular}

Many bacteria such as Vibrio and Pseudomonas sp. from marine fishes are being used as probiotics to target bacterial shrimp diseases mostly vibriosis caused by species of Vibrio bacteria. To date, several organisms isolated from different sources such as marine sediments, shrimp ponds, shrimp gut with species ranging from Bacillus, Streptomyces, Pseudomonas, as well as others including vibriosis have been reported to be sources of probiotics to promote an immune response in marine ecosystems [34,35]. Several species reported to be proper probiotic to improve the physiological function and prevent infectious diseases (vibriosis) of cultured Pacific white shrimp L. vannamei or the black tiger wild shrimp P. monodon as presented in Table 2 .

The organisms are dominated by species of Bacillus and Streptomyces. Lactobacillus, which is commonly used as human probiotic, also had effect 
on shrimp vibriosis. Others are purple non-sulfur bacteria Rhodobacter sphaeroides strains and Afifella marina as well as commercial probiotics in mixed or pure form. The formulated probiotic product composed primarily of nutrients, vitamins as well as a high concentration of the bacteria involved [19]. In consideration of the characteristics of probiotics applied in aquaculture, it should be remembered that unlike terrestrial probiotics applied in aquatic environment, which is influenced by certain factors due to the close interaction of marine animals with their environment; which give way for potential pathogens to establish themselves in the animal's external environment making their take up by the animals a normal occurrence through feeding or osmoregulation [27].

\section{MODE OF ACTION}

The mode of action of probiotics in the aquatic system is different to that of terrestrial animal [43]. In aquatic system, the mode of action of probiotics is either directly on the host or indirectly on the environment and sometimes involves both. In shrimp, just like other pisces, probiotics do not act just as disease control agents [44]. In aquatic animals, probiotics have several modes of action that confer benefits to their potential host [Figure 2].

The protection from pathogens after probiotic treatment could be attributed to the direct inhibition of pathogens or to the capability of probiotics in modulating the immune system of shrimp [45]. The beneficial effects of probiotics are products of several interrelated or dependent mechanisms. A pictorial representation of the different mechanisms highlighting the interrelationship of the probiotic actions is given in Figure 3. The putative probiotic can be added to the host or its ambient environment in several ways: (i) Addition to the artificial diet, (ii) addition to the culture water, (iii) bathing, and (iv) addition through live food [37].

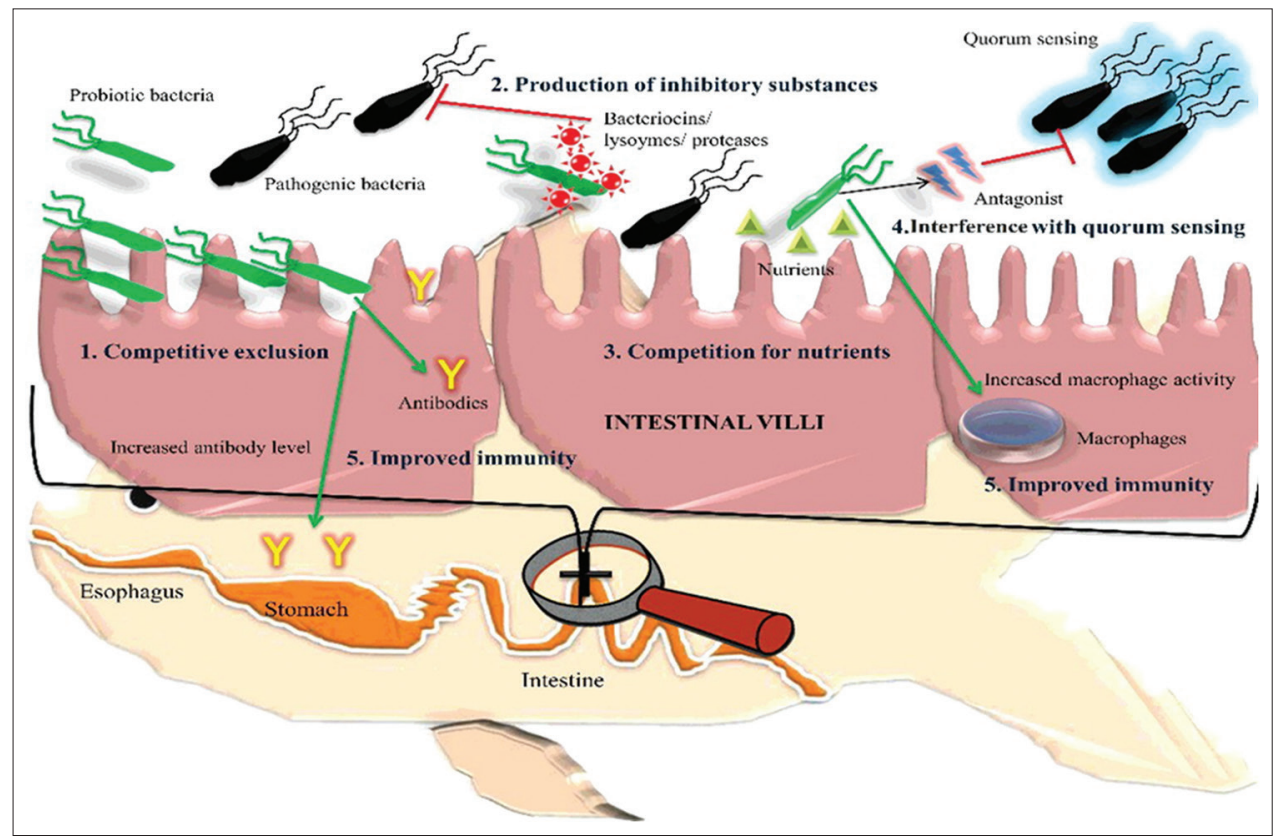

Figure 2: Mode of action of probiotics in the aquatic system

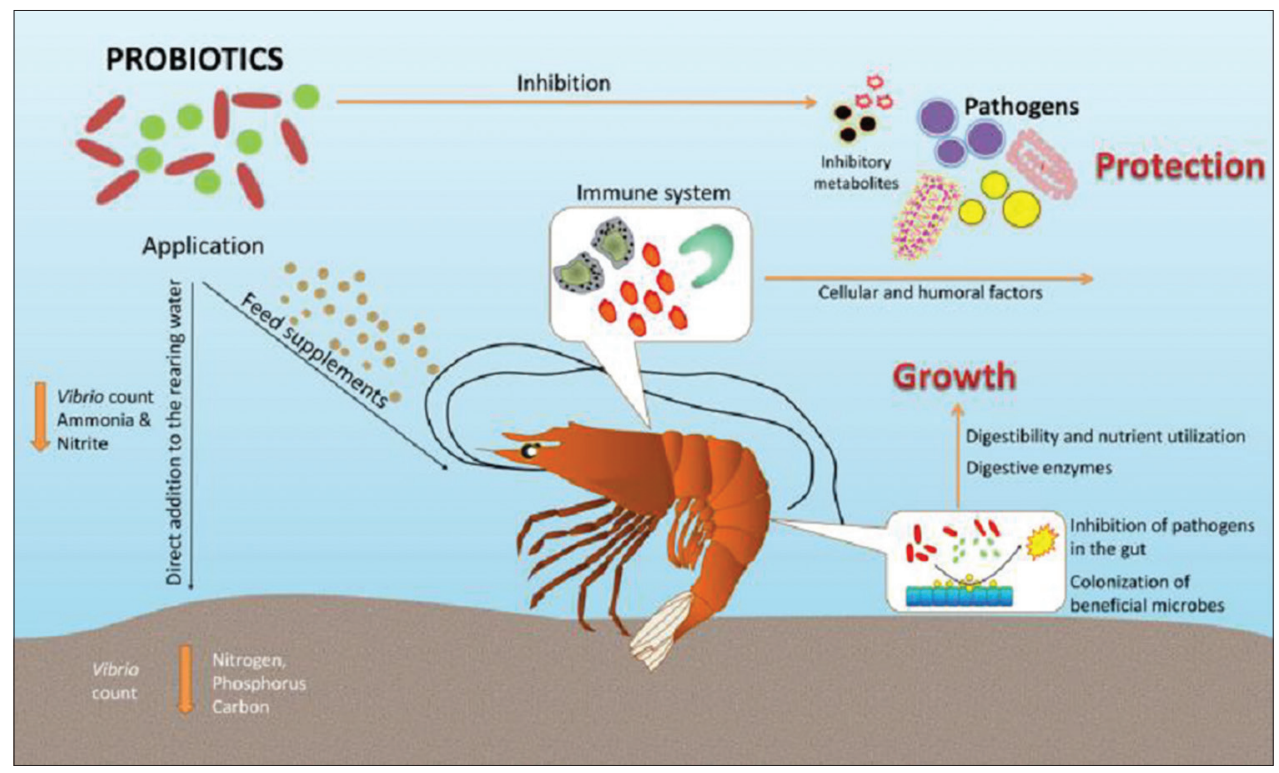

Figure 3: Interrelationship of the mechanisms of probiotic actions in shrimp 


\subsection{Stimulation of the Host Immunity}

Many studies showed that some bacteria produce compounds with an immune effect in fish and shrimp. In general, this effect of immunity could be improved by the probiotic in three general ways; first, activate the macrophage, that by the increasing ability to phagocytose microorganisms; second, by increasing systematic antibodies production; and third, by increasing local antibodies at mucus surfaces [46].

Irianto and Austin reported that feeding with 107 cells/g of feed of probiotics both Gram-negative and Gram-positive bacteria led to the stimulation of cellular rather than humeral immunity [47]. Even though the increase in erythrocytes number, lymphocytes and macrophages also enhanced the activity of lysozyme in 2 weeks, and the probiotics behaving like vaccines. Another study confirm an inhibitory effect against vibriosis in turbot by lactic acid bacteria, and also the study proposed mechanisms in this field that was by inhibition of the unliked microbes by metabolites typical of lactic acid bacteria; the microbial competition for essential nutrients [48].

\subsection{Competition for Space}

One of the major probiotics mechanism is the competition for space in shrimp aquaculture, as many of the bacterial pathogens behave attachment structures [6]. Space competition (adhesion sites) in tissues in the digestive tract is an antagonistic mechanism for probiotic to inhibit the action of pathogenic bacteria [18]. Different reports view the presence of lactic acid bacteria in the intestinal acid bacteria that constitute nonpathogenic members of the indigenous intestinal microbiota of healthy aquatic organism [48]. Furthermore, some probiotics like lactic acid bacteria strain served to fish through the food from GI tract (GIT) [49]. The attached pathogens such as Coliform and Clostridia could be removed by the adhesive probiotic bacteria, such as, and motivate their removal from the infected intestinal tract [50].

To cause diseases to a host, it will need to attach on the layer of mucosin the host GIT [51]. One mode of action of probiotic bacteria is to compete for sites of adhesion with the pathogens and hence the name "competitive exclusion." This ability of probiotic bacteria to out-compete pathogens in colonizing the gut and in adherence to the epithelial surface and consequently interfere with the pathogens adhesion is a desirable criterion in the probiotics selection [14,32]. Bacillus S11, for example, which isolated from P. monodon broodstock GIT, the results of a 100-day feeding with probiotic-supplemented and non-supplemented (control) feeds showed effective probiotic protection with $P$. monodon. $P$. monodon showed a significant development in growth, survival, and external appearance between the trialed two groups [35]. In addition, after challenging with adding a shrimp pathogen, Vibrio harveyi by immersion for 10 days with the aquaculture shrimp, all probiotic treated groups survived $100 \%$, and $26 \%$ of the control group survived, which suggested that probiotic Bacillus S11 is a competitive exclusion. On the other hand, some organic acid and volatile fatty acids (e.g. lactic, acetic, butyric, and propionic acids) produce by bacteria, which results in a reduction of GI lumen $\mathrm{pH}$ that can preventing opportunistic pathogenic microorganisms growth [52].

\subsection{Nutrients and Competition}

An important role can be played in the composition of the microbiota of the intestinal tract or ambient environment of cultured aquatic species by nutrients competition [18]. Increasing some bacteria such as bacillus and lactobacillus as a probiotic may cause decrease in the available substrate for some populations of bacteria [53]. Many studies indicate the presence of bacteria in the intestinal tract, which forms nonpathogenic members of the indigenous intestinal microbiota of healthy aquatic organism. Furthermore, such strains could be active in metabolism and grow more than pathogenic bacteria [49].

Usually probiotic bacteria are colonized in the intestine, permanently or temporarily by using the intestinal mucosa as a habitat; and successful bacteria are thriving well in the gut environment, where iron is available for their growth [18]. Smith and Davey (1993) showed that fluorescent strain pseudomonad bacteria during challenge test can beat the growth of Aeromonas salmonicida the fish pathogen, these results appear how the fluorescence is probably due to free iron competition [54,55]. The low-molecular-weight sideropheros and ferric iron-specific chelating agents can dissolve and precipitated iron in the gut and make it available for microbial growth [18].

Probiotics stimulate the growth and improve the nutrient digestion in aquatic organisms, and the aquaculture is an important option in the production of animal protein, it requires high-quality feeding by proper protein content to keep organisms healthy and favor growth [47,56]. Lara-Flores et al. found during studying the effects of strains of some bacteria that all the probiotic-supplemented diets resulted in growth higher than those with the control diets, they also found that probiotics could lower the effects of stress factors [56]. The detoxification of potentially harmful compounds in the diet by hydrolytic enzymes could improve the nutrients in organisms, including both of amylases and proteases, and production of different vitamins such as biotin and Vitamin B12 [47]. Venkat et al. observed significant growth for larvae of Macrobrachium rosenbergii fed diets with probiotics added and found that the protein gain $(>55 \%)$ and the protein efficiency ratio were significantly higher during treatments fed by probiotic [57].

\subsection{Production of Inhibitory Substances that Work on Pathogens}

Probiotic bacteria produce substances can beat other microbial populations with bactericidal or bacteriostatic effects those substances such as bacteriocins, hydrogen peroxide, siderophores, lysozymes, proteases, and many others [58]. The effects of Bacillus sp., for example, have been linked to the production of different antibiotics, bacteriocins, lysozymes, proteases, and hydrogen peroxide, and the alteration of $\mathrm{pH}$ values by the production of organic acids [18]. In aquaculture, several probiotics recorded antibacterial activity against many known pathogens including viruses [Table 3]. Bacillus megaterium strain increased the resistance by the shrimp, L. vannamei against WSSV, it was observed that probiotics such as Bacillus and Vibrio sp. could protect shrimp, L. vannamei against WSSV [59].

The antibacterial effect of bacteria results from factors such as the production of antibiotics, bacteriocins, siderophores, lysozyme, protease, hydrogen peroxide, the alteration of $\mathrm{pH}$ values, and the production of organic acids and ammonia [18]. Several compounds that may inhibit the growth of competing bacteria produces by Lactic acid bacteria and Bacillus, and the bacteriocins are one of the most important of those compounds [37,69]. Usually, these are proteins, or protein complexes, and produced by bacteria can have an antagonistic action against species that are closely related to the producer bacterium. Bacteriocins found in four classes: Antibiotics, small hydrophobic, heat-stable peptides, large heat-stable peptides, and complex bacteriocins: Probiotics with lipid and or carbohydrate [53]. 
Table 3: Applications of probiotics as pathogen inhibitor in aquaculture

\begin{tabular}{|c|c|c|}
\hline Probiotic bacteria & Applied to aquatic species & Reference \\
\hline Bacillus sp. & Penaeids & {$[2]$} \\
\hline Enterococcus faecium SF 68 & Anguilla anguilla & {$[60]$} \\
\hline Lactobacillus rhamnosus ATCC53103 & Oncorhynchus mykiss & [61] \\
\hline Micrococcus luteus A1-6 & Oncorhynchus mykiss & [47] \\
\hline Pseudomonas fluorescens & Oncorhynchus mykiss & [55] \\
\hline Pseudomonas fluorescens AH2 & Oncorhynchus mykiss & [61] \\
\hline Roseobacter sp. BS. 107 & Scallop larvae & [63] \\
\hline Saccharomyces cerevisiae, Saccharomyces exiguous, Phaffia rhodozyma & Litopenaeus vannamei & [64] \\
\hline Vibrio alginolyticus & Salmonids & [65] \\
\hline Vibrio fluvialis & Oncorhynchus mykiss & [42] \\
\hline Tetraselmis suecica & Salmo salar & [65] \\
\hline Lactococcus lactis & Epinephelus coioides & {$[68]$} \\
\hline
\end{tabular}

Table 4: Applications of probiotics for water quality improvement

\begin{tabular}{llc}
\multicolumn{1}{c}{ Probiotic bacteria } & Applied to aquatic species & Reference \\
Bacillus sp. NE 48 & Penaeus monodon & {$[75]$} \\
Bacillus NL 110, Vibrio sp. NE 17 & Macrobrachium rosenbergii & {$[20]$} \\
Lactobacillus acidophilus & Clarias gariepinus & {$[22]$} \\
Bacillus coagulans - SC8168 & Penaeus vannamei & {$[76]$} \\
Bacillus sp. Saccharomyces sp & Penaeus monodon & {$[77]$} \\
\hline
\end{tabular}

\subsection{Competition for Chemicals or Available Energy}

Microorganisms, such as known probiotic group lactic acid bacteria, use the essential nutrients; which used in the growth of a number of pathogens [70]. For example, the low-molecular-weight ferric iron-chelating agents called siderophores have an ability to dissolve precipitated iron or extract it from iron complexes, then it will be ready to use in bacterial growth [71]. Furthermore, the bacteria produce siderophore could be used as probiotics due to its ability to sequent ferric iron in an iron-low environment and make it unavailable for the growth of pathogenic bacteria [52].

\subsection{Improving Water Quality}

By adding probiotic strains of the Gram-positive genus Bacillus water quality improves. From several studies, it became proven that application of Gram-positive bacteria, Bacillus spp., is beneficial for improving the quality of the water system. In comparison to the Gramnegative bacteria, Bacillus sp. has ability to convert organic matter into carbon dioxide, that by converting the proportion of organic matter into a slime [14]. Since this bacterial group is more useful than Gramnegative in transforming the organic matter, regarding the suggestion that high levels of probiotics in production ponds mentainance, it became easy that during the growing season, fish aquacultures can lower the accumulation of dissolved and particulate organic carbon. This also can balance phytoplankton production. Bacterium Streptomyces used as a probiotic in the lab culture of $P$. monodon that results a good water quality parameter than the control trial also that was effective in the growth of cultured shrimp [Table 4]. Probiotics are also proven the capability of pond ecosystem manipulating such as microflora and the physicochemical conditions [72-74].

\subsection{Disease Control}

Lactobacillus rhamnosus ATCC (American Type Culture Collection, Rockville, MD, USA) was used in rainbow trout as probiotic for 51 days to reduce mortality by $A$. salmonicida. From the result, it was reduced from $52.6 \%$ to $18.9 \%$ when 109 cells $/ g$ were administered with feed when probiotic dose was increased to 1012 cells/g of feed the mortality reached $46.3 \%$ and increasing dosage does not necessarily improve protection against diseases [61]. Farmed shrimp survival increased, and feed conversion occurred when mixed cultures of probiotics were applied [26]. Meanwhile, in the study of mixed cultures of bacteria (Bacillus subtilis, Lactobacillus acidophilus, and Clostridium butyricum) and yeast (Saccharomyces cerevisiae), it registered enhancement of the non-specific immune parameters of tilapia Oreochromis niloticus such as lysozyme activity, migration and neutrophils, and plasma bactericidal activity, the result showed improvement of resistance to Edwardsiella tarda infection [78] [Table 5].

\section{CONCLUSION}

The business of the aquaculture of shrimp is growing and developing at a very fast rate throughout the world and contributes to high world production. The continuous use of antibiotics against infectious diseases in the aquaculture of shrimp and fish lead to a serious problem, while the overuse of antibiotics, which ultimately leads to diseases resistant to the antibiotic treatment such as Vibrio species. The successes are using probiotics, which is effective, and sustainable source against viral and bacterial pathogens encountered in shrimp aquaculture. However, many efforts have been served in the field of discovering probiotic products, and it became a fact and efficient to be used in aquaculture. Many application of probiotics in aquaculture clearly used, but there are needs for more efforts to understand the mechanisms of action to define selection for proper probiotics. Meanwhile, there is a lack in the studies of microbial aquaculture ecology and the relation with animal growth and water quality. 
Table 5: Probiotic bacteria used in shrimp aquaculture

\begin{tabular}{|c|c|c|c|}
\hline Probiotic bacteria & Source & Shrimp involved & Reference \\
\hline Streptomyces spp. & Marine sediment & Litopenaeus vannamei & {$[79]$} \\
\hline Bacillus megaterium & Mangrove sediments & Penaeus monodon & {$[80]$} \\
\hline Streptomyces fradiae & Mangrove sediments & Penaeus monodon & {$[80]$} \\
\hline Proteobacteria firmicutes & Commercial & Litopenaeus vannamei & {$[81]$} \\
\hline Streptomyces Spp. & Marine sediment & Penaeus monodon & {$[82]$} \\
\hline Lactobacillus plantarum & Cabbage prickle & Litopenaeus vannamei & {$[83]$} \\
\hline Bacillus subtilis & Shrimp culture ponds & Litopenaeus vannamei & {$[84]$} \\
\hline Probiotic mixture & Commercial & Litopenaeus vannamei & {$[85]$} \\
\hline Bacillus species & Shrimp pond & Penaeus monodon & {$[86]$} \\
\hline Bacillus licheniformis & Shrimp gut & Litopenaeus vannamei & {$[87]$} \\
\hline Purple non-sulfur bacteria & Shrimp pond & Litopenaeus vannamei & {$[88]$} \\
\hline
\end{tabular}

\section{REFERENCES}

1. Food and Agriculture Organization. The State of World Fisheries and Aquaculture. Rome: Food and Agriculture Organization; 2016.

2. Moriarty DJ. Control of luminous Vibrio species in Penaeid aquaculture ponds. Aquaculture 1999;164:351-8.

3. Flegel TW. Historic emergence, impact and current status of shrimp pathogens in Asia. J Invertebr Pathol 2012;110:166-73.

4. Joseph CV. Current trends in the Philippines shrimp aquaculture industry: A booming blue economy in the pacific. Oceanogr Fish Open Access J 2017;5:1-5.

5. Seibert $\mathrm{CH}$, Pinto AR. Challenges in shrimp aquaculture due to viral diseases: Distribution and biology of the five major Penaeid viruses and interventions to avoid viral incidence and dispersion. Braz $\mathrm{J}$ Microbiol 2012;43:857-64.

6. Karunasagar I, Ababouch L. Shrimp viral diseases, import risk assessment and international trade. Indian J Virol 2012;23:141-8.

7. Israngkura A, Sae-Hae S. A Review of Economic Impacts of Aquatic Animal Disease. In: Arthur JR, Phillips MJ, Subasinghe RP, Reantaso MB, McCrae IH editors. Primary Aquatic Animal Health Care in Rural, Small-Scale Aquaculture Development, Technical Proceedings of the Asia Regional Scoping Workshop. Rome: FAO Fisheries Technical Paper No. 406, FAO; 2002. p. 55-61.

8. Stentiford GD, Neil DM, Peeler EJ, Shields JD, Small HJ, Flegel TW, et al. Disease will limit future food supply from global crustacean fishery and aquaculture sectors. J Invertebr Pathol 2012;110:141-7.

9. Lightner DV. Biosecurity in shrimp farming: Pathogen exclusion through use of SPF stock and routine surveillance. J World Aquac Soc 2005;36:229-48.

10. David JW. Moriarty. Disease Control in Shrimp Aquaculture with Probiotic Bacteria Biomanagement Systems Pty. Microbial Biosystems: New Frontiers Proceedings of the $8^{\text {th }}$ International Symposium on Microbial Ecology Bell CR. Halifax, Canada: Atlantic Canada Society for Microbial Ecology; 1999.

11. Yanbo W, Qing GU. Effect of probiotics on white shrimp (Penaeus vannamei) growth performance and immune response. Mar Biol Res 2015;6:327-32.

12. Johnson SK. Handbook of Shrimp Diseases. Sea Grant Publication Number TAMU-SG. Texas, USA: Texas A and M University, College Station; 1990. p. 90-601.

13. Jayasree L, Janakiram P, Madhavi R. Characterization of Vibrio spp. associated with diseased shrimp from culture ponds of Andhra Pradesh (India). J World Aquac Soc 2006;37:523-32.

14. Balcazar JL, Blas ID, Ruiz-Zarzuela I, Cunningham D, Vendrell D, Muzquiz JL. Review: The role of probiotics in aquaculture. Vet Microbiol 2006;114:173-86.
15. Wang YB, Xu ZR. Probiotics treatment as a method of biocontrol in aquaculture. Feed Res 2004;12:42-5.

16. Fuller R. A review, probiotics in man and animals. J Appl Bacteriol 1987;66:365-78.

17. Kumar V, Suvra R, Meena DK, Sarkar UK. Application of probiotics in shrimp aquaculture: Importance, mechanisms of action, and methods of administration, Rev Fish Sci Aquac 2016;24:342-68.

18. Verschuere L, Rombaut G, Sorgeloos P, Verstraete W. Probiotic bacteria as biological control agents in aquaculture. Microbiol Mol Biol Rev 2000;64:655-71.

19. Gatesoupe FJ. The use of probiotics in aquaculture. Aquaculture 1999; 180:147-65.

20. Rahiman M, Yousuf J, Ambat T, Hatha M. Probiotic effect of Bacillus NL110 and Vibrio NE17 on the survival, growth performance and immune response of Macrobrachium rosenbergii (de Man). Aquac Res 2010;41:120-34.

21. Youping Y, Dongdong M, Shijiang L, Zhongkang W. Effects on growth and digestive enzyme activities of the Hepialus gonggaensis larvae caused by introducing probiotics. World J Microbiol Biotechnol 2011;27:529-33.

22. Dohail A, Abdullah M, Roshada H, Aliyu M. Effects of the probiotic, Lactobacillus acidophilus, on the growth performance, haematology parameters and immunoglobulin concentration in African catfish (Clarias gariepinus, Burchell 1822) fingerling. Aquac Res 2009;40:1642-52.

23. Tapia-Paniagua ST, Diaz-Rosales P, Leon-Rubio JM, De La Banda IG, Lobo C, Alarcon FJ, Chabrillon M, et al. Use of the probiotic Shewanella putrefaciens Pdp11 on the culture of senegalese sole (Solea senegalensis Kaup 1858) and gilthead sea bream (Sparus aurata L.). Aquac Int 2012;20:1025-39.

24. Dawicki S. New probiotic bacteria shows promise for use in shellfish aquaculture. Natl Ocean Atmos Adm 2012;4:495-2378.

25. Newaj-Fyzul A, Al-Harbi AH, Austin B. Review: Developments in the use of probiotics for disease control in aquaculture. Aquaculture 2014;431:1-11.

26. Wang YB, Xu ZR, Xia MS. The effectiveness of commercial probiotics in northern white use of live and dead probiotic cells in tilapia Oreochromis niloticus. Fisheries science shrimp Penaeus vannamei ponds. Fish Sci 2005;71:1036-41.

27. Hai N, Fotedar R. A Review of probiotics in shrimp aquaculture. J Appl Aquac 2015;22:251-66.

28. Ferreira GS, Bolívar NC, Pereira SA, Guertler C, Vieira FD, Mourino JL, et al. Microbial biofloc as source of probiotic bacteria for the culture of Litopenaeus vannamei. Aquaculture 2015;448:273-9.

29. Ramesh D, Vinothkanna A, Rai AK, Vignesh VS, Isolation of potential probiotic Bacillus spp. and assessment of their subcellular 
components to induce immune responses in Labeo rohita against Aeromonas hydrophila. Fish Shellfish Immunol 2015;45:268-76.

30. Tapia PA, Diaz RP, Leon RJ. Use or the probiotic Shewanella putrefaciens Pdp11 on the culture of sole (Solea senegalensis, Kaup 1858) and gilthead seabream (Sparaus aurata L.). Aquac Int 2012;21:1-15.

31. Delduca A, Cesar DE, Diniz CG, Abreu PC. Evaluation of the presence and efficiency of potential probiotic bacteria in the gut of tilapia (Oreochromis niloticus) using the fluorescent in situ hybridization technique. Aquaculture 2013;388-91:115-21.

32. Lazado CC, Caipang CM, Brinchmann MF, Kiron V. In vitro adherence of two candidate probiotics from Atlantic cod and their interference with the adhesion of two pathogenic bacteria. Vet Microbiol 2011;148:252-9.

33. Hai NV, Fotedar R. A review of probiotics in shrimp aquaculture. J Appl Aquac 2010;22:251-66.

34. Onarheim AM, Raa J. Characteristics and Possible Biological Significance of an Autochthonous Flora in the Intestinal Mucosa in Sea-Water Fish. In: Lesel R, editor. Microbiology in Poecilotherms. Proceedings of the International Symposium on Microbiology in Poekilotherms. Paris, France: Elsevier Science Publishers B.V.; 1990. p. 197-201.

35. Rengpipat S, Phianphak W, Piyatiratitivorakul S, Menasveta P. Effects of a probiotic bacterium on black tiger shrimp Penaeus monodon survival and growth. Aquaculture 1998;167:301-13.

36. Queiroz JF, Boyd CE. Effects of a bacterial inoculum in channel catfish ponds. J World Aquac Soc 1998;29:67-73.

37. Gildberg A, Mikkelsen H, Sandaker E, Ringo E. Probiotic effect of lactic acid bacteria in the feed on growth and survival of fry of Atlantic cod (Gadus morhua) Hydrobiologia 1997;352:279-85.

38. Douillet PA, Langdon CJ. Use of a probiotic for the culture of larvae of the pacific oyster (Crassostrea gigas Thunberg). Aquaculture 1994;119:25-40.

39. Harzeveli AR, VanDuffel H, Dhert P, Swing J, Sorgeloos P. Use of a potential probiotic Lactococcuslactis AR21 strain for the enhancement of growth in the rotifer Brachionus plicatilis (Muller). Aquac Res 1998;29:411-7.

40. Dharmaraj S, Dhevendaran K. Evaluation of Streptomyces as a probiotic feed for the growth of ornamental fish Xiphophorus helleri. Food Technol Biotechnol 2010;48:497-504.

41. Hernandez LH, Barrera TC, Mejia JC. Effects of the commercial probiotic Lactobacillus casei on the growth, protein content of skin mucus and stress resistance of juveniles of the porthole live bearer, Poecilopsis gracilis (Poecilidae). Aquac Nutr 2010;16:407-11.

42. Lin SH, Guan Y, Luo L, Pan Y. Effects of dietary chitosan oligosaccharides and Bacillus coagulans on growth, innate immunity and resistance of koi (Cyprinus carpio koi). Aquaculture 2012;342:36-41

43. Zorriehzahra MJ, Delshad ST, Adel M, Tiwari R, Karthik K, Dhama K, et al. Probiotics as beneficial microbes in aquaculture: An update on their multiple modes of action: A review. Vet Q 2016;36:228-41.

44. Defoirdt T, Sorgeloos P, Bossier P. Alternatives to antibiotics for the control of bacterial disease in aquaculture. Curr Opin Microbiol 2011;14:251-8.

45. $\mathrm{Fu} \mathrm{N}$, Chen XD. Towards a maximal cell survival in convective thermal drying processes. Food Res Int 2011;44:1127-49.

46. Fuller R. Probiotics: History and Development of Probiotics. New York: Chapman and Hall; 1992.

47. Irianto A, Austin B. Use of probiotics to control furunculosis in rainbow trout, Oncorhynchus mykiss (Walbaum). J Fish Dis 2002;25:333-42.

48. Vzzquez JA, Gonzalez MP, Murado MA. Effects of lactic acid bacteria cultures on pathogenic microbiota from fish. Aquaculture 2005;245:149-61.
49. Joborn A, Olsson JC, Westerdahl A, Conway PL, Kjelleberg S. Colonization in the fish intestinal tract production of inhibitory substances in intestinal mucus and faecal extracts by Carnobacterium sp. strain K1. J Fish Dis 1997;20:383-92.

50. Lee YK, Lim WL, Teng AC, Ouwehand EM, Tuomola EM, Salminen S. Quantitative approach in the study of adhesion of lactic acid bacteria to intestinal cells and their competition with Enterobacteria. Appl Environ Microbiol 2000;66:3692-7.

51. Adams CA. The probiotic paradox: Live and dead cells are biological response modifiers. Nutr Res Rev 2010;23:37-46.

52. Tinh NT, Dierckens K, Sorgeloos P, Bossier P. A review of the functionality of probiotics in the larviculture food chain. Mar Biotechnol 2007;10:1-12.

53. Fooks LJ, Gibson GR. Probiotics as modulators of the gut flora. Br J Nutr 2002;88:39-49.

54. Smith P, Davey S. Evidence for the competitive exclusion of Aeromonas salmonicida from fish with stress-inducible furunculosis by Pseudomonas fluorescens. J Fish Dis 1993;16:521-4.

55. Gram L, Melchiorsen J, Spanggaard B, Huber I, Nielsen TF. Inhibition of Vibrio anguillarum by Pseudomonas fluorescens AH2, a possible probiotic treatment of fish. Appl Environ Microbiol 1999;65:969-73.

56. Lara-Flores M, Olvera-Novoa MA, Guzman-Mendez BE, Lopez-Madrid W. Use of the bacteria Streptococcus faecium and Lactobacillus acidophilus, and the yeast Saccharomyces cerevisiae as growth promoters in nile tilapia (Oreochromis niloticus). Aquaculture 2003;216:193-201.

57. Venkat HK, Sahu NP, Jain KK. Effect of feeding Lactobacillus based probiotics on the gut micro flora, growth and survival of post larvae of Macrobranchium reosenbergii (de man). Aquac Res 2004;35:501-7.

58. Servin A. Antagonistic activities of Lactobacilli and Bifidobacteria against microbial pathogens. Microbiol Rev 2004;28:405-40.

59. Balcazar JL. Evaluation of Probiotic Bacterial Strains in Litopenaeus vannamei. Final Report. Guayaquil: National Center for Marine and Aquaculture Research; 2003.

60. Chang CI, Liu WY. An evaluation of two probiotic bacterial strains, Enterococcus faecium SF68 and Bacillus toyoi, for reducing Edwardsiellosis in cultured European eel, Anguilla Anguilla L. J Fish Dis 2002;25:311-5.

61. Gram L, Lovold T, Nielsen J, Melchiorsen J, Spanggaard B. In vitro antagonism of the probiont Pseudomonas fluorescens strain AH2 against Aeromonas salmonicida does not confer protection of salmon against furunculosis. Aquaculture 2001;199:1-11.

62. Spanggaard B, Huber I, Nielsen J, Sick EB, Pipper CB, Martinussen T, et al. The probiotic potential against Vibriosis of the indigenous microflora of rainbow trout. Environ Microbiol 2001;3:755-65.

63. Ruiz-Ponte C, Samain JF, Sanchez JL, Nicolas JL. The benefit of a Roseobacter species on the survival of scallop larvae. Mar Biotechnol 1999;1:52-9.

64. Scholz U, Garcia DG, Riccque D, Cruz SL, Vargas AF, Latchford J. Enhancement of Vibriosis resistance in juvenile Penaeus vannamei by supplementation of diets with different yeast products. Aquaculture 1999;176:271-83.

65. Austin B, Stuckey LF, Robertson PA, Effendi I, Griffith DR. A probiotic strain of Vibrio alginolyticus effective in reducing diseases caused by Aeromonas salmonicida, Vibrio anguillarum and Vibrio ordalii. J Fish Dis 1995;18:93-6.

66. Abdullah AM, Hashim R, Aliyu PM. Evaluating the use of Lactobacillus acidophilus as a biocontrol agent against common pathogenic bacteria and the effects on the haematology parameters and histopathology in African catfish, Clarias gariepinus juveniles. Aquac Res 2011;42:196-209.

67. Moreira SD, Medeiros SS, Pereira LL, Romano LA, Wasielesky W, Cupertino BE. The use of probiotics during the nursery rearing or the pink shrimp Farfantepenaeus brasiliensis (Latreille, 1817) in a zero exchange system. Aquac Res 2011;21:1-10. 
68. Zhang S, Sing Y, Long M, Wei Z. Does dietary administration of Lacto coccuslactis modulate the gut microbiota of grouper, Epinephelus coioides. J World Aquac Soc 2012;43:198-207.

69. Ali A. Probiotics in Fish Farming. Evaluation of a Bacterial Mixture. Umea, Sweden: PhD Thesis. Swedish University of Agricultural Sciences; 2000.

70. Brown M. Modes of action of probiotics: Resent developments. J Anim Vet Adv 2011;10:1895-900.

71. Neilands JB. Iron absorption and transport in microorganisms. Ann Rev Nutr 1981;1:27-46.

72. Boonthai T, Vuthiphandchai V, Nimrat S. Probiotic bacteria effects on growth and bacterial composition of black tiger shrimp (Penaeus monodon). Aquac Nutr 2011;17:634-44.

73. Nikoskelainen S, Ouwehand A, Salminen S, Bylund G. Protection of rainbow trout (Oncorhynchus mykiss) from furunculosis by Lactobacillus rhamnosus. Aquaculture 2001;198:229-36.

74. Zokaeifar H, Balcazar JL, Saad CR, Kamarudin MS, Sijam K, Arshad A, et al. Effects of Bacillus subtilis on the growth performance, digestive enzymes, immune gene expression and disease resistance of white shrimp, Litopenaeus vannamei. Fish Shellfish Immunol 2014;33:683-9.

75. Wang YB, Li JR, Lin J. Probiotics in aquaculture: Challenges and outlook. Aquaculture 2008;281:1-4.

76. Zhou XX, Wang YB, Li WF. Effect of probiotic on larvae shrimp (Penaeus vannamei) based on water quality, survival rate and digestive enzyme activities. Aquaculture 2009;287:349-53.

77. Shishehchian F, Yusoff FM, Shariff M. The effects of commercial bacterial products on macrobenthos community in shrimp culture ponds. Aquac Int 2001;9:429-36.

78. Taoka Y, Maeda H, Jo JY. Assessing the use of a dietary probiotic/ prebiotic as an enhancer of spine foot rabbitfish Siganus rivulatus survival and growth. Fish Sci 2006;72:755-66.

79. Garcia-Benal M. Probiotic effect of Streptomyces spp. on shrimp (Litopenaeus vannamei) post larvae challenged with Vibrio parahaemolyticus. Aquac Nutr 2017;24:865-71.

80. Aftabuddin S, Kashem MA, Kader MA. Use of Streptomyces fradiae and Bacillus megaterium as probiotics in the experimental culture of tiger shrimp Penaeus monodon (Crustacea, Penaeidae). AACL Bioflux 2013;6:253-67.

81. Vargas F, Martinez M, Arvay M, Canchola EV, Gollas T, Porchas M. Immuno physiological response of pacific white shrimp exposed to a probiotic mixture of Proteobacteria and Firmicutes in farm conditions. N Am J Aquac 2016;78:193-202.

82. Das S, Ward LR, Burke C. Screening of marine Streptomyces spp. for potential use as probiotics in aquaculture. Aquaculture 2010;305:32-41.

83. Chiu CH, Guu YK, Liu CH, Pan TM, Cheng W. Immune responses and gene expression in white shrimp, Litopenaeus vannamei, induced by Lactobacillus plantarum. Fish Shellfish Immunol 2007;23:364-77.

84. Balcazar JL, Rojas-LunaT. Inhibitory activity of probiotic Bacillus subtilis UTM 126 against Vibrio species confers protection against Vibriosis in juvenile shrimp (Litopenaeus vannamei). Curr Microbiol 2007;55:409-12.

85. Hostins B, Lara G, Decamp O, Cesar DE, Wasielesky W. Efficacy and variations in bacterial density in the gut of Litopenaeus vannamei reared in a BFT system and in clear water supplemented with a commercial probiotic mixture. Aquaculture 2017;480:58-64.

86. Leopoldo S, Laranja Q, Schryver P, Gradys L, Amar EC, Aerts M, et al. High amorphous poly-beta-hydroxybutyrate (PHB) content in a probiotic Bacillus strain displays better protective effects in Vibriochallenged gnotobiotic Artemia. Aquaculture 2018;487:15-21.

87. Franco R, Martin AA, Dayami S, Jorge S, Hector C, Jaime M, et al. Evaluation of two probiotics used during farm production of white shrimp Litopenaeus vannamei (Crustacea: Decapoda). Aquac Res 2016;48:1-15.

88. Chumpol S, Kantachote D, Rattanachuay P, Vaddhakul V, Nitota T. In vitro and in vivo selection of probiotic purple non sulphur bacteria with an ability to inhibit shrimp pathogens: Acute hepatopancreatic necrosis disease-causing Vibrio parahaemolyticus and other Vibrios. Aquac Res 2017;48:3182-97.

\section{How to cite this article:}

Jamal MT, Abdulrahman IA, Al Harbi M, Chithambaran S. Probiotics as

alternative control measures in shrimp aquaculture: A review. J App Biol

Biotech. 2019;7(03):69-77. DOI: 10.7324/JABB.2019.70313 